\title{
Pengembangan payment for development right (PDR) untuk konservasi air pada lahan milik di Kecamatan Pamulihan, Kabupaten Sumedang, Jawa Barat
}

\author{
Y. Barus ${ }^{1 *}$, H. Ramdan ${ }^{1}$ \\ 1Program Studi Magister Biomanajemen, Sekolah Ilmu dan Teknologi Hayati, Institut Teknologi Bandung, \\ Bandung, Indonesia
}

\begin{abstract}
Abstrak.
Hak-hak yang melekat pada lahan milik, tak jarang dapat merugikan kawasan lain. Payment for Development Right (PDR) ialah program bersifat sukarela dan insentif, yang mengkompensasi pemilik jasa ekosistem dengan tujuan melindungi secara permanen lahan, namun tetap mempertahankan kepemilikan dan manajemen swasta. Program PDR ini banyak memberikan keuntungan pada negara yang telah mengimplementasikannya. Di Indonesia program ini belum pernah diterapkan, maka dilakukanlah penelitian ini yang bertujuan: 1) Menganalisis kondisi wilayah, 2) Mengestimasi nilai manfaat jasa ekosistem air yang berasal dari lahan milik, dan 3) Menyusun rekomendasi implementasi PDR. Besar nilai PDR yang dihitung bagi tutupan lahan pertanian, perkebunan, dan sawah bernilai lebih besar dibandingkan dengan Willingness to Pay (WTP) masyarakat pengguna jasa ekosistem. Berdasarkan hasil analisis regresi, WTP masyarakat dipengaruhi secara nyata oleh besar pendapatan masyarakat. Kondisi selama penelitian dirangkum dalam faktor-faktor SWOT, dan diperoleh faktor SWOT tertinggi pada kelompok internal yaitu Strength, dan pada kelompok eksternal yaitu Threat. Kedua faktor ini menjadi dasar dari rekomendasi pengimplementasian program PDR, yakni dengan mengadakan program pra-PDR yang diharapkan dapat meningkatkan pengertian masyarakat akan jasa ekosistem, mempersiapkan kelembagaan, sistem regulasi, serta pendataan jasa lingkungan pada daerah tersebut.
\end{abstract}

Kata kunci: jasa ekosistem, konservasi, lahan milik, payment for development right, willingness to pay

\begin{abstract}
.
Rights inherent in private land, can harm other regions. Payment for Development Right is a voluntary and incentive program, which compensates the owner of ecosystem services with the aim of permanently protecting land but still maintaining private ownership and management. PDR program provides many benefits to the countries that have implemented it. In Indonesia this program has never been implemented. This research was conducted with several objectives: 1) Analyse the condition of the region, 2) Estimate the value of the benefits of water ecosystem services from private land, and 3) Formulate recommendations for the implementation of PDR. The value of PDR calculated for the cover of agricultural land, plantations, and rice fields has a greater value compared to the Willingness to Pay of the people who use ecosystem services. Based on the results of the regression analysis, community's WTP was significantly affected by the amount of community income. The conditions during the study were summarized in SWOT factors, and the highest SWOT factor was obtained in the internal group: Strength, and in the external group: Threat. Both of these factors form the basis of the recommendations for implementing the PDR program, by holding a pre-PDR program that is expected to increase people's understanding of ecosystem services, prepare institutions, regulatory systems, and collect data on environmental services in the area.
\end{abstract}

Keywords: ecosystem services, conservation, private land, payment for development right, willingness to pay

\section{PENDAHULUAN}

Provinsi Jawa Barat terdiri atas 18\% kawasan hutan, sedangkan sisanya merupakan lahan milik privat. Hak-hak yang melekat pada lahan milik cenderung mutlak untuk digunakan atau dimanfaatkan sesuai dengan kebutuhan atau kepentingannya. Tak jarang kepentingan pemilik lahan tersebut dapat merugikan kawasan lain. Sebaliknya, menjaga ekosistem dengan menyediakan keanekaragaman hayati yang diperlukan untuk berfungsinya

\footnotetext{
${ }^{*}$ Korespondensi Penulis

E-mail: yedidadilona@gmail.com
} 
ekosistem secara sehat, akan menghasilkan banyak manfaat bagi masyarakat dari rekreasi, perlindungan banjir hingga udara bersih. Seringkali, insentif tidak disediakan bagi pemilik lahan pribadi karena melestarikan dan memberikan manfaat-manfaat ini. Sementara itu, harga tanah yang dijual untuk pertanian juga jauh lebih kecil dari nilai tanah yang dijual untuk pembangunan sehingga banyak pemilik lahan pertanian di daerah pinggiran kota, cenderung menjual tanah pertanian untuk pembangunan bagi kebutuhan jangka panjang.

Penegakan hukum lingkungan yang selama ini dilakukan cenderung bersifat represif, yakni memberikan hukuman kepada perusak atau pencemar lingkungan hidup. Hal ini terkesan bersifat memaksa dan terlebih masyarakat tidak merasakan adanya manfaat langsung dari usahanya menjaga lingkungan. Terutama masyarakat di daerah-daerah pedesaan dengan kurangnya pengetahuan dan kesadaran akan kehidupan ekosistem yang seimbang. Sistem insentif dalam memberlakukan hukum lingkungan dapat lebih membantu masyarakat untuk merasakan efek dari regulasi yang dijalankan. Tomich et al. (2004) menyebutkan dua hal yang mempengaruhi praktik pengelolaan lahan terkait dengan peningkatan jasa lingkungan yakni (1) regulasi, berbasis pendekatan perintah dan kontrol dan pendekatan administratif yang lebih tradisional dan (2) penghargaan, mengacu pada berbagai ide baru pengaturan insentif jasa lingkungan, biasanya akan mendorong motivasi penyedia jasa lingkungan untuk mengelola dan melindungi lanskap mereka dengan lebih baik.

Program PDR (Payment for Development Right) atau Pembelian Hak Pembangunan adalah program bersifat sukarela dan berbasis insentif yang mengkompensasi pemilik jasa ekosistem dengan tujuan melindungi secara permanen lahan yang produktif, sensitif, atau estetis, namun tetap mempertahankan kepemilikan dan manajemen swasta. Program ini dinilai memberi manfaat besar bagi negara-negara yang telah mengimplementasikannya, seperti sebagian besar negara bagian di Amerika (seringkali disebut Purchase of Development Right). Program ini juga dirasakan sangat menguntungkan di Indonesia, sebab banyak pemilik lahan pertanian di Indonesia mempunyai tingkat kemiskinan (khususnya dalam bentuk uang tunai) yang cukup tinggi. Dengan hanya menjual hak pembangunannya, pemilik dapat mengubah sebagian kekayaan yang diikat di lahan mereka menjadi uang tunai, tanpa melepaskan kepemilikan lahan atau menggunakan kapasitas produktifnya (Miller and Krieger 2004).

Mengingat program Payment for Development Right ini bersifat sukarela, maka supaya dapat berjalan, diperlukan pengertian masyarakat mengenai manfaat dari jasa ekosistem yang dapat dihasilkan. Nurfatriani dan Handoyo (2007) menyatakan bahwa kawasan mata air yang menyediakan manfaat hidrologis masih dinilai rendah, khususnya untuk pemanfaatan air yang berasal 
dari mata air yang langsung dimanfaatkan oleh masyarakat untuk kebutuhan rumah tangga. Pengertian masyarakat atas nilai manfaat, dalam hal ini sumber daya air, perlu diuji, apakah masyarakat mengerti bahwa fungsi tersebut didatangkan dari sebuah usaha konservasi di wilayah lain. Oleh karena itu, sebelum mengimplikasikan program PDR ini di Indonesia, sangat perlu untuk mengidentifikasi besar nilai manfaat pengguna terhadap jasa ekosistem.

\section{METODOLOGI}

\subsection{Lokasi kajian dan waktu penelitian}

Pengambilan data penelitian ini meliputi desa/wilayah pengguna jasa ekosistem yaitu Desa Cijeruk, Ciherang dan Girimukti, serta desa/wilayah penyedia jasa ekosistem yaitu Desa Cigendel. Keempat desa ini terletak di Kecamatan Pamulihan, Kabupaten Sumedang, Jawa Barat. Jasa ekosistem berupa manfaat hidrologis tepatnya berpusat di kawasan mata air Pelton. Penelitian dilaksanakan pada bulan Februari-Mei 2019.

\subsection{Prosedur analisis data}

Prosedur analisis data dalam mengumpulkan data yang diperlukan untuk menjawab tujuan dari penelitian ini ditampilkan pada Tabel 1.

Tabel 1. Data yang dibutuhkan dalam penelitian.

\begin{tabular}{|c|c|c|c|c|}
\hline No & Tujuan & $\begin{array}{l}\text { Output yang } \\
\text { diharapkan }\end{array}$ & Metode & $\begin{array}{l}\text { Bahan } \\
\text { dan Alat }\end{array}$ \\
\hline 1 & $\begin{array}{l}\text { Menganalisis } \\
\text { kondisi wilayah } \\
\text { penyedia serta } \\
\text { dan pengguna } \\
\text { jasa ekosistem }\end{array}$ & $\begin{array}{l}\text { - Peta wilayah } \\
\text { pengguna dan } \\
\text { penyedia } \\
\text { - Karakteristik air: } \\
\text { kualitas, kuantitas, } \\
\text { dan kontinuitas } \\
\text { - Jumlah kebutuhan } \\
\text { air wilayah } \\
\text { pengguna }\end{array}$ & $\begin{array}{ll}\text { - } & \text { Hydro Ecosystem Services } \\
\text { Spatial Assessment } \\
\text { (HESSA) atau Pemetaan } \\
\text { - Kualitas air: uji } \\
\text { laboratorium } \\
\text { - Kuantitas: pengukuran } \\
\text { debit mata air } \\
\text { - Kontinuitas: wawancara } \\
\text { - Jumlah kebutuhan air }\end{array}$ & ArcGIS \\
\hline 2 & $\begin{array}{l}\text { Mengestimasi } \\
\text { nilai manfaat jasa } \\
\text { ekosistem air } \\
\text { yang berasal dari } \\
\text { lahan milik }\end{array}$ & $\begin{array}{l}\text { Nilai manfaat jasa } \\
\text { ekosistem di dalam } \\
\text { Rupiah per } \\
\text { penggunaan air }\end{array}$ & $\begin{array}{l}\text { Nilai manfaat bagi } \\
\text { wilayah pengguna: } \\
\text { Contingent Valuation } \\
\text { Method (Willingness to } \\
\text { Pay) } \\
\text { - Nilai manfaat bagi } \\
\text { wilayah penyedia: } \\
\text { Perhitungan biaya PDR }\end{array}$ & Kuesioner \\
\hline 3 & $\begin{array}{l}\text { Menyusun } \\
\text { rekomendasi } \\
\text { implementasi } \\
\text { PDR }\end{array}$ & $\begin{array}{l}\text { Strategi } \\
\text { pengimplementasian } \\
\text { PDR pada wilayah } \\
\text { penelitian }\end{array}$ & Analisis SWOT-AHP & $\begin{array}{l}\text { Alat } 4 \mathrm{Rs} \text {, } \\
\text { wawancara } \\
\text { expert }\end{array}$ \\
\hline
\end{tabular}




\section{HASIL DAN PEMBAHASAN}

\subsection{Karakteristik wilayah penyedia dan pengguna}

Suatu jasa ekosistem air dalam wujud mata air, terletak di Desa Cigendel, Kelurahan Pamulihan, Kabupaten Sumedang. Mata air yang dinamakan Pelton ini tentu memberikan jasa ekosistem bagi lingkungannya. Adapun wilayah pemberi dan penerima jasa ekosistem dari mata air ini, dibatasi dan dianalisis secara spasial menggunakan HESSA (Ramdan 2015), dan terbentuklah peta wilayah, dengan wilayah penyedia jasa ekosistem dengan luas sebesar 151,189 hektar, dan luas wilayah pengguna sebesar 269,072 hektar.

Karakteristik mata air Pelton dideskripsikan dalam 3K: Kontinuitas, Kuantitas dan Kualitas yang penjelasannya tersaji pada Tabel 2.

Tabel 2. Karakteristik mata air Pelton.

\begin{tabular}{lll}
\hline Kuantitas & Kualitas & Kontinuitas \\
\hline Debit Air mata & Berdasarkan hasil uji mutu air minum & Hasil wawancara pemilik mata \\
air Pelton yang & dengan standar baku air minum yang & air Pelton, jumlah air pada \\
terukur sebesar & tertulis pada PerMenKes Nomor 492 & musim kemarau berkurang \\
0,41 L/detik & Tahun 2010 tentang Persyaratan & hingga 50\% dibandingkan pada \\
& Kualitas Air Minum, maka air di mata & musim hujan. Namun tetap dapat \\
& air Pelton tidak memenuhi syarat air & memenuhi kebutuhan pengguna \\
& minum dikarenakan pH yang bernilai & air secara langsung, sekalipun \\
& $4,5(\mathrm{pH}$ standar air minum 6-7,5). & terkadang ada keluhan. \\
\hline
\end{tabular}

Suplai air dari mata air Pelton, diketahui berdasarkan debit air yang terekam, yakni sebesar 0,41 L/detik yang sama dengan $35.424 \mathrm{~L} / \mathrm{hari}$, atau 1.062.720 L/bulan. Nilai ini kemudian dibandingkan dengan jumlah permintaan air dari setiap tutupan lahan. Hasil dari perhitungan, kebutuhan air wilayah pengguna jasa ekosistem ditampilkan pada Tabel 3 berikut ini.

Tabel 3. Kebutuhan air wilayah pengguna jasa ekosistem.

\begin{tabular}{lc}
\hline \multicolumn{1}{c}{ Jenis Tutupan Lahan } & Kebutuhan Air per Bulan (Liter) \\
\hline Sawah & 57.173 .200 \\
Pertanian & 90.234 .259 \\
Pemukiman & 7.319 .700 \\
\hline Total Kebutuhan Air & 154.727 .159 \\
\hline
\end{tabular}

Berdasarkan jumlah kebutuhan air tersebut, maka mata air Pelton hanya mampu mencukupi 0,69\% kebutuhan air wilayah pengguna jasa ekosistem. Berdasarkan karakteristik mata air Pelton tersebut, maka debit air tidak dapat memenuhi seluruh permintaan pengguna jasa ekosistem. Sementara, ketersediaan air bersifat kontinu, namun kualitasnya kurang layak untuk diminum. Dari karakteristik tersebut, maka sebenarnya mata air Pelton ini memberikan manfaat, namun manfaat ini kurang dirasakan dengan maksimal. 


\subsection{Estimasi nilai manfaat jasa ekosistem}

\subsubsection{Wilayah pengguna jasa ekosistem}

Pada wilayah pengguna jasa ekosistem, dilakukan estimasi nilai manfaat masyarakat dalam satuan Rupiah, yakni dengan menghitung Willingness to Pay. Alasan penggunaan WTP dalam barang atau jasa publik adalah karena harga atau nilai pasarnya gagal direfleksikan kepada masyarakat atau konsumen ataupun karena keabsenan transaksi-transaksi pasar (Camacho-Cuena et al. 2004). Berdasarkan hasil wawancara terhadap 30 orang responden yang berada di wilayah pengguna, sebanyak $33 \%$ responden bersedia membayar jasa ekosistem. Sisa $67 \%$ dari responden yang tidak mau membayar umumnya beralasan karena merasa jasa ekosistem yang diberikan wilayah penyedia tidak berpengaruh besar bagi kegiatan ekonomi dan penghidupan sehari-hari responden.

Kemudian dari 33\% responden yang menyatakan bersedia membayar, diberikan pertanyaan lanjutan mengenai jumlah harga yang bersedia dibayarkan. Cara menanyakan kesediaan membayar dengan menggunakan payment card model, responden diberikan tawaran menggunakan kartu yang berisi nilai uang mulai dari yang terendah sampai batas responden mengatakan tidak untuk nilai yang ditawarkan.

Secara keseluruhan, rata-rata nilai WTP 10 orang responden dari yang bersedia membayar adalah sebesar Rp 44.000. Jika skala ini diperbesar dengan mengalikannya dengan total penduduk di wilayah pengguna jasa ekosistem yang sebesar 2.440, maka estimasi total WTP masyarakat adalah sebesar Rp 107.360.000. Nilai WTP sebesar Rp 107.360.000 ini merupakan kesediaan masyarakat untuk membayar jasa ekosistem yang disediakan oleh wilayah penyedia seluas 151,189 hektar, yang berarti untuk 1 hektar jasa ekosistem yang disediakan oleh wilayah penyedia, nilai yang bersedia dibayarkan masyarakat adalah Rp 710.105 per hektar pemilik lahan. Nilai ini memberikan arti, bahwa pengguna jasa ekosistem bersedia membayar Rp 710.105 untuk menjadi kompensasi atas hak pembangunan yang dijual dalam satu hektar tanah melalui program PDR ini. Tabel 4 menunjukkan rata-rata nilai WTP masyarakat untuk setiap jenis tutupan lahan.

Tabel 4. Rata-rata kesediaan membayarkan per jenis tutupan lahan.

\begin{tabular}{lcc}
\hline Jenis Tutupan Lahan & Rata-Rata Skor Persepsi Masyarakat & Rata-Rata WTP (Rp/ha) \\
\hline Hutan & 42,75 & 71.875 \\
Sawah & 29,75 & 0,00 \\
Pertanian & 32,67 & 12.500 \\
Tanah Terbuka & 32,50 & $4.166,67$ \\
Perkebunan & 31,40 & 8.000 \\
Pemukiman & 27,75 & 6.250 \\
\hline
\end{tabular}


Faktor-faktor yang mempengaruhi masyarakat dalam menentukan nilai Willingness to Pay (WTP) manfaat jasa lingkungan hidrologi mata air Pelton menggunakan beberapa variabel yakni: a) besar pendapatan, b) tingkat pendidikan, c) lama tinggal, d) jumlah anggota keluarga, serta e) tingkat pemahaman masyarakat terhadap nilai jasa ekosistem sebagai variabel independen (pengaruh) dan variabel nilai WTP sebagai variabel dependen (terpengaruh). Variabel-variabel tersebut dianalisis dengan menggunakan persamaan regresi berganda untuk mengetahui variabel yang diduga akan berpengaruh nyata terhadap nilai WTP responden. Hasil analisis menggunakan Software SPSS menunjukkan hasil yang dirangkum pada Tabel 5.

Tabel 5. Hasil analisis statistik.

\begin{tabular}{lrcc}
\hline \multicolumn{1}{c}{ Variabel } & Koefisien Regresi & Thitung & Sig. \\
\hline Konstanta & $-29.387,83$ & & 0,397 \\
Besar pendapatan per bulan (a) & $31.769,63$ & 2,478 & $0,038^{*}$ \\
Tingkat pendidikan (b) & - & 1,085 & 0,718 \\
Lama tinggal (c) & - & $-0,357$ & 0,948 \\
Jumlah anggota keluarga (d) & - & 2,071 & 0,892 \\
Skor valuasi ekosistem (e) & - & 0,898 & 0,545 \\
\hline
\end{tabular}

Keterangan: *signifikan pada taraf nyata $5 \%$.

Hasil analisis regresi menggunakan metode Stepwise yang ditampilkan pada Tabel 5, menunjukkan bahwa variabel besar pendapatan memiliki nilai signifikansi 0,038, yang menandakan bahwa besar pendapatan berpengaruh signifikan terhadap nilai WTP masyarakat $(p<0,05)$. Sementara variabel tingkat pendidikan, lama tinggal, jumlah anggota keluarga dan skor valuasi ekosistem memiliki signifikansi $>0,05$, yang artinya keempat variabel ini tidak mempengaruhi WTP masyarakat.

Nilai $\mathrm{R}^{2}$ atau koefisien determinasi yang diperoleh menggunakan analisis regresi menggunakan variabel $a, b, c, d$ dan e adalah 0,434. Nilai $R^{2}$ ini menunjukkan bahwa korelasi antara variabel besar pendapatan, tingkat pendidikan, lama tinggal dan jumlah anggota keluarga, serta pemahaman masyarakat mengenai nilai manfaat memiliki pengaruh kontribusi $43,4 \%$ terhadap variabel Y (Willingness to Pay).

\subsubsection{Wilayah penyedia jasa ekosistem}

Nilai manfaat jasa ekosistem, selain dinilai dari Willingness to Pay masyarakat pengguna jasa ekosistem, juga dihitung berdasarkan biaya yang akan diterima oleh penyedia jasa ekosistem untuk menggantikan hak pembangunan yang dijual. Besar insentif yaitu besar hak pembangunan merupakan Nilai Harapan Tanah (NHT) dikurang nilai harga jual setempat (Hernawan et al. 2010). 
Besar Discount Rate dalam perhitungan NPV (Net Present Value) dan NJOP menggunakan acuan dari besar bunga Bank Indonesia (BI). Adapun BI rate Juli 2019 dan rata-rata inflasi Juli 2018 - Juli 2019 yang diumumkan BI berturutturut adalah $5,75 \%$ dan 3,00\%, sehingga bunga aktualnya adalah $2,75 \%$. Waktu yang ditetapkan dalam perhitungan NPV dan NJOP adalah selama 20 tahun (analogi dari lamanya masa pakai bangunan).

Perhitungan NPV menggambarkan pendapatan yang akan diperoleh pemilik lahan dengan tidak menjual lahannya yang bersifat produktif. Nilai NPV yang akan dihitung adalah nilai NPV dari tutupan lahan perkebunan, pertanian dan sawah. Perhitungan NPV didasarkan pada arus kas setiap tahunnya, yang merupakan total pendapatan dikurang dengan biaya. Biaya tetap hanya diperhitungkan ke dalam arus kas pada tahun pertama, sedangkan biaya variabel diperhitungkan setiap tahunnya. Total keuntungan serta biaya-biaya yang diakumulasi menjadi arus kas dalam satu tahun ditampilkan pada Tabel 6.

Tabel 6. Keuntungan per tahun jenis tutupan lahan pertanian, perkebunan dan sawah.

\begin{tabular}{lrrr}
\hline Keterangan & Pertanian & Perkebunan & Sawah \\
\hline NJOP (Rp/m ${ }^{2}$ ) & 20.000 & 36.000 & 20.000 \\
Harga Jual Komoditas (Rp/kg) & 2.500 & 9.000 & 4.500 \\
Produktivitas (kg/ha) & 4000 & 3700 & 4500 \\
Luas tanam (ha) & 27,62 & 26,36 & 6,56 \\
Penerimaan (Rp/panen ) & 276.200 .000 & 877.788 .000 & 132.840 .000 \\
Biaya Tetap (Rp) & 14.942 .420 & 65.925 .437 & 9.525 .120 \\
Biaya Variabel (Rp) & 88.494 .480 & 323.924 .860 & 6.896 .000 \\
Total Biaya Panen (Rp) & 103.436 .900 & 389.850 .297 & 45.237 .760 \\
Keuntungan (Rp) & 172.763 .100 & 487.937 .703 & 87.602 .240 \\
Keuntungan tanpa Biaya Tetap (Rp) & 187.705 .520 & 553.863 .140 & 97.127 .360 \\
\hline
\end{tabular}

Keuntungan per tahun ini dikalikan dengan bunga 2,75\% setiap tahunnya. Nilai Harapan Tanah dirata-rata, dan kemudian diselisihkan dengan besarnya nilai NJOP lahan tersebut. Nilai PDR yang diperoleh pada setiap jenis tutupan lahan ditampilkan pada Tabel 7.

Tabel 7. Nilai PDR atas dasar nilai harapan tanah (NHT) dan harga jual lahan per hektar.

\begin{tabular}{lcrr}
\hline Jenis Tutupan Lahan & NJOP & \multicolumn{1}{c}{ NPV } & \multicolumn{1}{c}{ Nilai PDR } \\
\hline Pertanian (Rp) & 156.460 .016 & 58.447 .287 & 98.012 .728 \\
Perkebunan (Rp) & 281.628 .028 & 179.897 .956 & 101.730 .072 \\
Sawah (Rp) & 156.460 .016 & 127.069 .234 & 29.390 .782 \\
\hline
\end{tabular}

Hasil perhitungan WTP yang telah diperoleh adalah sebesar Rp 710.105 per hektar, sedangkan biaya PDR yang diperoleh dari Tabel 7 terlampau jauh lebih besar dibandingkan dengan nilai WTP masyarakat, baik pada jenis tutupan lahan pertanian, perkebunan maupun sawah. Hasil ini mengindikasikan bahwa pelaksanaan program PDR tidak dapat berjalan apabila masyarakat pengguna 
jasa ekosistem diharuskan membayar biaya PDR dengan jumlah seperti yang tertera pada Tabel 7 dalam satu tahun.

Kondisi ini disebabkan oleh beberapa faktor, antara lain tingginya harga jual lahan, rendahnya pendapatan yang dihasilkan dari lahan pertanian, perkebunan dan sawah, serta rendahnya pemahaman masyarakat akan jasa ekosistem yang dihasilkan lahan penyedia. Padahal, jasa ekosistem yang disediakan selama ini sangat berguna bagi masyarakat di wilayah pengguna. Mata air di kawasan penyedia jasa ekosistem selama ini digunakan untuk kebutuhan hidup sehari-hari seperti air minum, masak, irigasi dan MCK.

Selain terhadap manfaat hidrologi, rendahnya persepsi masyarakat juga terjadi pada hasil pertanian. Masyarakat sepenuhnya menyerahkan pendapatan pertanian pada mekanisme pasar, sehingga pada saat panen raya harga jual hasil pertanian berupa sayur-sayuran dan padi menjadi jatuh. Hal ini mendorong petani menjual lahan tempat bekerjanya yang umumnya kemudian dikonversi menjadi permukiman atau guna lahan lain. Hal tersebut mencerminkan belum adanya kesadaran publik terhadap kemungkinan kehilangan sumber daya air, sumber makanan, dan buah-buahan. Hal ini merupakan penyebab utama kesulitan implementasi PDR pada wilayah penelitian.

Besarnya biaya insentif PDR harus tetap diperoleh pemilik lahan sebesar biaya penjualan hak pembangunan yang terhitung. Jika dilakukan hal sebaliknya, yakni dengan mengurangi biaya PDR sesuai dengan kesediaan masyarakat, maka jasa ekosistem tidak terpelihara dengan maksimal, karena tidak dihargai seperti sebagaimana seharusnya. Hal ini juga menimbulkan ketimpangan keadilan antar pemilik lahan dan pengguna jasa ekosistem. Menyiasati nilai Willingness to Pay masyarakat yang lebih kecil dibandingkan dengan biaya PDR ini, maka diperlukan subsidi dari pemerintah untuk menggantikan total kompensasi atas penjualan hak pembangunan.

\subsection{Analisis SWOT}

Sebelumnya, telah diperoleh hasil penelitian mengenai pengimplementasian program PDR di wilayah Kecamatan Pamulihan, Kabupaten Sumedang, mulai dari studi literatur mengenai program ini, karakteristik wilayah, karakteristik sosial dan ekonomi masyarakat, dan analisis nilai manfaat. Berdasarkan hasil penelitian tersebut, maka kondisi-kondisi yang terjadi dikategorikan sebagai Strength, Weakness, Opportunities dan Threat yang dirangkum dalam Tabel 8.

\subsubsection{Strength (kekuatan)}

\section{1) Peningkatan partisipasi masyarakat}

Program PDR ini merupakan program yang berbasis kesepakatan bersama. Oleh karena itu, masyarakat perlu berpartisipasi dalam pengambilan keputusan 
mengenai perjanjian konservasi dalam program ini. Tak hanya itu, sistem kesepakatan ini mampu meningkatkan tanggung jawab pribadi masyarakat, dalam hal ini sebagai pengambil keputusan. Keterlibatan masyarakat dalam penyelenggaraan jasa lingkungan hidup ditulis dalam Bab IX PerGub Jawa Barat Nomor 33 Tahun 2019 tentang Petunjuk Pelaksanaan Peraturan Daerah Provinsi Jawa Barat Nomor 5 Tahun 2015 tentang Pengelolaan Jasa Lingkungan Hidup.

\section{2) Menitikberatkan keadilan dan kesetaraan hak}

Pemahaman masyarakat Indonesia selama ini, sumber daya air adalah milik negara dan dikuasai oleh negara untuk dipergunakan sebesar-besarnya bagi kemakmuran rakyat, sesuai dengan bunyi pasal 33 ayat 3 UUD 1945. Akibatnya, sumber daya air dipandang sebagai barang bebas (free goods) sehingga diambil dan dimanfaatkan secara berlebihan, sehingga menimbulkan pengikisan sumber daya (dissipasipation resource), sumber daya air tidak terdistribusi sesuai dengan tempat dan waktu yang dibutuhkan, dimana menimbulkan kekeringan dan banjir pada wilayah tertentu (Arsyad dan Rustiadi 2012). Di satu sisi, sumber daya air yang ada pada lahan milik tersebut, selama ini digunakan oleh masyarakat lain untuk kegiatan produksi dan konsumsi, tetapi tidak adanya kompensasi atas pemanfaatan air tersebut, yang mana pengadaannya mungkin melibatkan tindakan-tindakan konservasi dari pihak penyedia air. Di sisi lain, apabila pemilik lahan tidak menjaga ekosistem lahan, fungsi hidrologis dapat mengalami penurunan, sehingga berakibat pada kegiatan produksi masyarakat yang selama ini memanfaatkan air mengalami penurunan juga. Dengan kesepakatan melalui Program PDR, hak pembangunan penyedia sumber daya air dijual-belikan, sehingga pengguna air dapat membeli dan memanfaatkan secara bebas, sementara pemilik lahan yang menyediakan sumber daya air bertanggung jawab atas hak bangun yang telah ia jual, untuk mentaati perjanjiannya dengan pembeli hak.

\section{3) Meningkatkan pertumbuhan ekonomi desa}

Pengimplementasian program ini mampu meningkatkan ekonomi desa, baik pada wilayah desa penyedia jasa ekosistem, serta pengguna jasa ekosistem. Pada wilayah penyedia jasa ekosistem, masyarakat difasilitasi untuk menjual suatu fungsi, masyarakat tidak perlu melakukan banyak usaha untuk menjualnya. Uang yang diperoleh dari hasil penjualan inipun dapat digunakan masyarakat secara langsung. Hal ini dapat meningkatkan pendapatan masyarakat per bulan, dan secara regional dapat meningkatkan pertumbuhan ekonomi desa di wilayah penyedia. Sementara di wilayah pengguna jasa ekosistem, peningkatan perlindungan terhadap ekosistem di wilayah penyedia dengan program PDR mampu meningkatkan hasil produksi, dan keberlanjutan 
usaha masyarakat, dan pada akhirnya mampu meningkatkan perekonomian desa di wilayah pengguna jasa ekosistem.

\subsubsection{Weaknesses (kelemahan)}

\section{1) Sistem administrasi dan regulasi yang kompleks}

Jika merujuk pada teknis pelaksanaan PDR di negara bagian Amerika (Virginia), maka kesepakatan yang terjadi harus didata dengan baik dan teratur, termasuk soal pendaftaran, pendanaan, dan pemeliharaan wilayah. Hal ini akan cukup sulit dan memakan waktu untuk membentuk sistem administrasi dan regulasi di wilayah penelitian, terutama jika kewajiban ini dibebankan kepada pemerintah desa.

\section{2) Perlu bergantung dengan pihak luar}

Pelaksanaan program PDR ini melibatkan penilaian terhadap nilai suatu lahan. Penilaian bagi lahan tidak hanya berkenaan dengan administrasi, namun juga mengenai manfaat ekosistem. Penilaiannya perlu dilakukan oleh lembaga yang tersertifikasi dalam memberikan penilaian, seperti asesor dari bank, konsultan lingkungan atau akademisi. Kondisi di wilayah ini, belum ada lembaga, atau bagian dari pemberdayaan masyarakat yang dapat menghitung total nilai manfaat jasa ekosistem. Tidak hanya itu saja, kuasa hukum juga perlu terlibat untuk mewadahi perjanjian yang telah disepakati. Artinya kesepakatan dalam program PDR ini tidak hanya melibatkan dua pihak: masyarakat serta pemerintah daerah, tetapi pihak atau lembaga luar, dan isu sumber daya manusia ini menjadi pertimbangan dalam keberlanjutan program PDR.

\section{3) Luas lahan per individu di wilayah penyedia kecil}

Apabila berkaca dengan sistem pelaksanaan PDR di Amerika, yang mana penjualan hak pembangunan merupakan inisiatif dari pemilik lahan, maka hal ini menjadi sulit karena kondisi di wilayah penelitian, luas lahan yang dimiliki tiap-tiap individu ukurannya kecil. Oleh karena itu, penjualan satu pemilik lahan tidak memberikan efek berarti bagi penyedia jasa ekosistem. Penjualan hak pembangunan perlu dilakukan secara simultan oleh beberapa pemilik lahan, atau satu pemilik lahan namun dengan areal yang luas supaya memberikan dampak yang terasa bagi lahan pengguna jasa ekosistem. Luas lahan yang kecil ini mengakibatkan perlunya ada kesamaan persepsi antar sesama pemilik lahan di wilayah penyedia jasa ekosistem untuk bersama-sama menjual hak membangunnya.

\subsubsection{Opportunities (peluang)}

\section{1) Desa terletak di wilayah pembangunan}

Letak desa yang berada di wilayah pembangunan. Wilayah penyedia jasa ekosistem berjarak sekitar 2 kilometer dengan pintu tol Cisumdawu, yang kini 
tengah (Mei 2019) dalam tahap pembangunan. Selanjutnya, diprediksi ada kemungkinan muncul banyaknya kebutuhan lahan untuk pembangunan. Hal ini menjadi kesempatan bagi Program PDR berkembang di wilayah penelitian karena akan adanya peningkatan tekanan penjualan lahan untuk pembangunan di wilayah penyedia ekosistem (Desa Cigendel), sementara masyarakat perlu menjaga lahan-lahan produktif.

\section{2) Telah banyak berkembang metode dan penelitian mengenai pemetaan wilayah jasa ekosistem}

Pemetaan dalam program PDR ini berfungsi untuk mengetahui batasan wilayah yang merupakan pengguna, dengan wilayah yang menjadi penyedia jasa ekosistem. Saat ini, adanya metode HESSA, serta metode-metode lain yang terus berkembang seiring dengan perkembangan teknologi, akan memudahkan pemetaan identifikasi wilayah penyedia dan pengguna, yang kelak akan sangat berguna membatasi wilayah dalam pelaksanaan program PDR.

\section{3) Dukungan pemerintah mengenai pengalokasian dana bagi konservasi wilayah}

Adanya perintah bagi BUMN, BUMS untuk mengalokasikan dana CSR sebesar 10\%, dan bagi gubernur, bupati/wali kota untuk mengalokasikan 1\% dana APBD bagi konservasi sumber daya alam yang artinya ada besar bantuan yang tersedia untuk pelaksanaan konservasi, yang termasuk salah satunya adalah program PDR ini.

\section{4) Konsep imbal jasa lingkungan atau PES (payment for ecosystem service) yang sudah diterapkan di Indonesia}

Konsep PES ini sudah diterapkan di beberapa lokasi di Indonesia antara lain Sumber Jaya (Provinsi Lampung), Kuningan-Cirebon (Provinsi Jawa Barat), Sungai Wain (Provinsi Kalimantan Timur), dan sebagainya (Fauzi and Anna 2013). Skema PES berbasis mekanisme pasar dan bersifat sukarela dalam pengelolaan dan perlindungan lingkungan (Herbert et al. 2010). Karena kemiripan kedua konsep ini, maka penelitian dan lembaga yang terlibat dalam penerapan konsep PES dapat digunakan kembali, atau digunakan dengan perubahan untuk penerapan konsep PDR di Indonesia.

\subsubsection{Threats (ancaman)}

\section{1) Valuasi masyarakat terhadap jasa ekosistem rendah}

Seperti pada penelitian yang telah dilakukan, tingkat pengertian masyarakat mengenai jasa ekosistem keduanya ada pada tingkatan yang nonsustainable. Hal ini dapat terlihat dari nilai WTP yang lebih rendah dibandingkan dengan nilai manfaat wilayah penyedia jasa ekosistem. Masyarakat di wilayah pengguna jasa ekosistem tidak menyadari bahwa air yang digunakannya selama 
ini merupakan hasil perlindungan terhadap jasa ekosistem di wilayah penyedia. Kesadaran masyarakat soal jasa ekosistem ini berpengaruh besar terhadap minat masyarakat untuk melakukan penjualan dan pembelian jasa ekosistem.

\section{2) Jasa hidrologis tidak memenuhi permintaan wilayah pengguna}

Dalam penelitian yang telah dilakukan, kuantitas air yang disediakan mata air Pelton hanya memenuhi $0,69 \%$ dari permintaan masyarakat di wilayah penyedia akan air (mata air Pelton bukanlah satu-satunya mata air di wilayah penyedia jasa ekosistem yang menjadi sumber bagi wilayah penyedia). Selain rendah secara kuantitas, kualitas air yang bersumber dari mata air Pelton memiliki $\mathrm{pH}$ yang rendah sehingga air ini tidak layak dikonsumsi.

\section{3) Belum adanya lembaga independen yang khusus menangani konservasi lahan di Indonesia}

Diperlukan lembaga yang secara khusus menangani konservasi lahan, yang akan berfungsi secara teknis untuk melakukan pengadaan dana, sumber daya manusia, dan bantuan-bantuan yang diperlukan dalam pelaksanaan program ini. Seperti halnya pelaksanaan PDR di Amerika, lembaga yang disebut dengan Land Trust adalah lembaga independen yang memberi kemudahan bagi pelaksana program PDR dengan mengambil peran sebagai pihak perantara, khususnya dalam pendanaan dan pelaksanaan penilaian manfaat terhadap wilayah yang akan dijual hak bangunnya.

Tabel 8. Analisis SWOT.

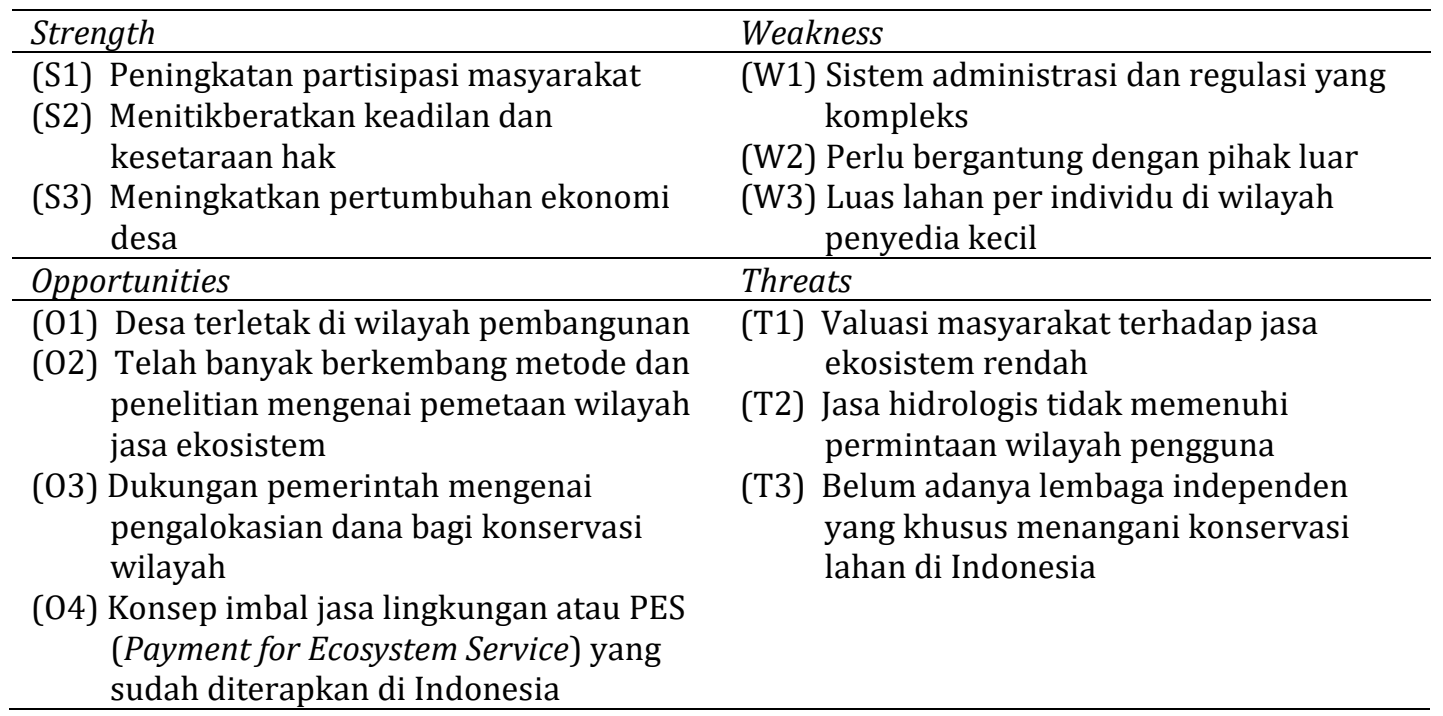

\subsubsection{Penggunaan metode AHP}

Berdasarkan hasil identifikasi SWOT, dilakukan pembobotan untuk masing-masing faktor ini dengan metode AHP yang bertujuan untuk 
menentukan kepentingan relatif antar faktor-faktor dalam SWOT. Dalam AHP, dilakukan perbandingan berpasangan yang didasari oleh skala perbandingan yang sudah terstandarisasi (Albayrak and Erensal 2004). Pada penelitian ini, expert yang melakukan pembobotan ini antara lain dosen-dosen, serta Dinas Lingkungan Hidup Jawa Barat. Hasil pembobotan ditunjukkan pada Tabel 9.

Tabel 9. Prioritas dan consistency ratio dari perbandingan kelompok dan faktor SWOT dalam pengimplementasian PDR.

\begin{tabular}{|c|c|c|c|c|c|c|}
\hline $\begin{array}{l}\text { Kelompok } \\
\text { SWOT }\end{array}$ & $\begin{array}{c}\text { Nilai } \\
\text { Prioritas }\end{array}$ & & Faktor SWOT & CR & $\begin{array}{l}\text { Nilai } \\
\text { Prioritas } \\
\text { Lokal }\end{array}$ & $\begin{array}{c}\text { Nilai } \\
\text { Prioritas } \\
\text { Global }\end{array}$ \\
\hline \multirow[t]{3}{*}{$\begin{array}{l}\text { Strength } \\
\text { (Kekuatan) }\end{array}$} & \multirow[t]{3}{*}{0,425} & (S1) & $\begin{array}{l}\text { Peningkatan partisipasi } \\
\text { masyarakat }\end{array}$ & \multirow[t]{3}{*}{0,00} & 0,473 & 0,201 \\
\hline & & (S2) & $\begin{array}{l}\text { Menitikberatkan keadilan dan } \\
\text { kesetaraan hak }\end{array}$ & & 0,255 & 0,108 \\
\hline & & (S3) & $\begin{array}{l}\text { Meningkatkan pertumbuhan } \\
\text { ekonomi }\end{array}$ & & 0,272 & 0,116 \\
\hline \multirow[t]{3}{*}{$\begin{array}{l}\text { Weakness } \\
\text { (Kelemahan) }\end{array}$} & \multirow[t]{3}{*}{0,173} & (W1) & $\begin{array}{l}\text { Sistem administrasi dan regulasi } \\
\text { yang kompleks }\end{array}$ & \multirow[t]{3}{*}{0,10} & 0,517 & 0,089 \\
\hline & & (W2) & $\begin{array}{l}\text { Perlu bergantung dengan pihak } \\
\text { luar }\end{array}$ & & 0,125 & 0,022 \\
\hline & & (W4) & $\begin{array}{l}\text { Luas lahan per individu di } \\
\text { wilayah penyedia kecil }\end{array}$ & & 0,358 & 0,062 \\
\hline \multirow[t]{4}{*}{$\begin{array}{l}\text { Opportunities } \\
\text { (Peluang) }\end{array}$} & \multirow[t]{4}{*}{0,199} & (01) & $\begin{array}{l}\text { Desa terletak di wilayah } \\
\text { pembangunan }\end{array}$ & \multirow[t]{4}{*}{0,07} & 0,213 & 0,042 \\
\hline & & $(02)$ & $\begin{array}{l}\text { Telah banyak berkembang } \\
\text { metode dan penelitian mengenai } \\
\text { pemetaan jasa ekosistem }\end{array}$ & & 0,207 & 0,041 \\
\hline & & (03) & $\begin{array}{l}\text { Dukungan pemerintah } \\
\text { mengenai pengalokasian dana } \\
\text { bagi konservasi wilayah }\end{array}$ & & 0,312 & 0,062 \\
\hline & & (04) & $\begin{array}{l}\text { Konsep Imbal Jasa Lingkungan } \\
\text { atau PES (Payment for } \\
\text { Ecosystem Service) yang sudah } \\
\text { diterapkan di Indonesia }\end{array}$ & & 0,269 & 0,054 \\
\hline \multirow[t]{3}{*}{$\begin{array}{l}\text { Threat } \\
\text { (Ancaman) }\end{array}$} & \multirow[t]{3}{*}{0,203} & (T1) & $\begin{array}{l}\text { Valuasi masyarakat terhadap } \\
\text { jasa ekosistem rendah }\end{array}$ & \multirow[t]{3}{*}{0,00} & 0,594 & 0,121 \\
\hline & & (T2) & $\begin{array}{l}\text { Jasa hidrologis tidak memenuhi } \\
\text { permintaan wilayah pengguna }\end{array}$ & & 0,157 & 0,031 \\
\hline & & (T3) & $\begin{array}{l}\text { Belum adanya lembaga } \\
\text { independen yang khusus } \\
\text { menangani konservasi lahan di } \\
\text { Indonesia }\end{array}$ & & 0,249 & 0,051 \\
\hline
\end{tabular}

Berdasarkan kuesioner kepada pakar mengenai prioritas masing-masing faktor SWOT, maka diperoleh faktor SWOT tertinggi yaitu Strength, dengan nilai prioritas 0,425. Jika dibagi menjadi faktor internal (S dan W) serta faktor eksternal (O dan T), maka dalam faktor internal, Strength yang menjadi faktor terkuat sementara pada faktor eksternal, Threat, atau ancaman yang juga menjadi faktor terkuat. 
Dalam kelompok Strength, faktor Strength yang paling berbobot paling besar yaitu S1 (peningkatan partisipasi masyarakat). Faktor inipun menjadi nilai prioritas tertinggi diantara faktor lain dalam seluruh kelompok SWOT. Peningkatan partisipasi masyarakat menjadi kekuatan yang dapat digunakan untuk mengatasi ancaman (Threat). Sementara, di kelompok Threat, faktor yang paling kuat yaitu T1 antara lain tingkat valuasi masyarakat yang rendah. Dari kedua kondisi yang paling mempengaruhi pengimplementasian program PDR di wilayah penelitian, maka disusunlah rekomendasi yang sekiranya mampu memanfaatkan kekuatan (Strength) khususnya kekuatan berupa faktor partisipasi masyarakat, untuk mengatasi ancaman (Threat), khususnya valuasi masyarakat yang rendah.

\section{KESIMPULAN DAN SARAN}

Kondisi lingkungan di wilayah penyedia jasa ekosistem tidak dapat memenuhi kebutuhan masyarakat pengguna jasa ekosistem dan tidak bersifat berkelanjutan sehingga diperlukan perbaikan lingkungan untuk memaksimalkan jasa ekosistem. Biaya Payment for Development Right (PDR) untuk mengkompensasi penjualan hak pembangunan lebih besar nilainya, baik pada tutupan lahan pertanian, perkebunan dan sawah dibandingkan dengan kesediaan masyarakat untuk membayar jasa ekosistem (WTP). Harga penjualan hak pembangunan yang tidak dapat dipenuhi oleh masyarakat, yang berimplikasi kepada tidak dapat berjalannya PDR jika seluruh biaya kompensasi ditanggung oleh masyarakat pengguna jasa ekosistem. Pengimplementasian program PDR terancam oleh rendahnya valuasi masyarakat pada wilayah penelitian. Sementara, kekuatan dari terlaksananya program ini adalah peningkatan partisipasi masyarakat.

\section{DAFTAR PUSTAKA}

Albayrak E and Erensal YC. 2004. Using analytic hierarchy process (AHP) to improve human performance: an application of multiple criteria decision making problem. Journal of Intelligent Manufacturing 15:491-503.

Arsyad S dan Rustiadi E. 2012. Penyelamat tanah, air, dan lingkungan. Yayasan Obor Indonesia. Jakarta.

Camacho-Cuena E, García-Gallego A, Georgantzís N and Sabater-Grande G. 2004. An experimental validation of hypothetical willingness to pay for a recyclable product. Environmental and Resource Economics 27:313-335.

Fauzi A and Anna Z. 2013. The complexity of the institution of payment for environmental services: a case study of two Indonesian PES scheme. Ecosystem Services 6:54-63. 
Herbert T, Vonada R, Jenkins M and Bayon R. 2010. Environmental funds and payments for ecosystem services. RedLAC. Rio de Janeiro.

Hernawan E, Kartodiharjo H, Darusman D dan Soedomo S. 2010. Prinsip pembagian biaya-manfaat menggunakan model pembelian hak membangun (PDR). JMHT 2:73-83.

Miller G and Krieger D. 2004. Payment for development rights: preserving farmland and open space. Planning Commissioners Journal 23:1-7.

Nurfatriani F dan Handoyo. 2007. Nilai ekonomi manfaat hidrologis hutan di DAS Brantas Hulu untuk pemanfaatan non komersial. Jurnal Sosial Ekonomi 3:193-234.

PerGub (Peraturan Gubernur) Jawa Barat Nomor 33 Tahun 2019 tentang petunjuk pelaksanaan Peraturan Daerah Provinsi Jawa Barat Nomor 5 Tahun 2015 tentang pengelolaan jasa lingkungan hidup.

PerMenKes (Peraturan Menteri Kesehatan) Nomor 492 Tahun 2010 tentang persyaratan kualitas air minum.

Ramdan H. 2015. Aplikasi HESSA (Hydro Ecosystem Services Spatial Assessment) untuk pemetaan wilayah penyedia dan pengguna air di kawasan hutan pegunungan [Prosiding]. Prosiding Seminar Nasional Masyarakat Diversitas Indonesia 1(7):1719-1724.

UUD (Undang-Undang Dasar) Negara Republik Indonesia Tahun 1945.

Tomich TP, Thomas DE and van Noordwijk M. 2004. Environmental services and land use change in Southeast Asia: from recognition to regulation or reward?. Agriculture, Ecosystems \& Environment 104:229-244. 